\title{
A Review of the Construction Techniques of Rumah Kutai, Perak
}

\author{
Khairul Fikri Khairudin, Nurul Hamiruddin Salleh, \\ Srazali Aripin
}

\author{
Kulliyyah of Architecture and Environmental Design, \\ International Islamic University Malaysia, Malaysia
}

khairul.fikri.khairudin@gmail.com, hamiruddin@iium.edu.my, srazali@iium.edu.my

\begin{abstract}
Rumah Kutai in Perak is amongst the oldest surviving traditional Malay house and is gradually disappearing from the indigenous cultural landscape of Malaysia. The subject of the research is construction techniques of the traditional Malay houses which is emphasized on the indigenous house of Perak, Rumah Kutai. This research, basically exploring on how Rumah Kutai is being constructed from the beginning until the end. Also, to examine the construction techniques especially on the jointing system (tanggam) of several components in Rumah Kutai. The research aims to study the construction techniques of traditional Rumah Kutai.

Keywords: Kutai; Traditional Malay house; Construction technique; Tanggam

eISSN 2514-751X C 2019. The Authors. Published for AMER ABRA cE-Bs by e-International Publishing House, Ltd., UK. This is an open-access article under the CC BY-NC-ND license (http://creativecommons.org/licenses/bync-nd/4.0/). Peer-review under responsibility of AMER (Association of Malaysian Environment-Behaviour Researchers), ABRA (Association of Behavioural Researchers on Asians) and CE-Bs (Centre for EnvironmentBehaviour Studies), Faculty of Architecture, Planning \& Surveying, Universiti Teknologi MARA, Malaysia.

https://doi.org/10.21834/aje-bs.v4i12.335
\end{abstract}




\subsection{Introduction}

This paper basically explores on how Rumah Kutai is being constructed from the beginning until the end. Also, the construction techniques of several components in Rumah Kutai will be analyzed and documented. This is the way to sustain the used or acknowledge the existence of tanggam probably for future reference as indicated by Sabil \& Utaberta (2011). Kutai House or also be called as Rumah Kutai is a traditional type of Malay house that is indigenous to Perak. As the time passed by, the construction of traditional Malay house or Kutai house is no longer practiced by the younger generation. The term of "traditional" seems no longer valid in the current era. A study on Rumah Kutai is basically to explore the history and the origin of Rumah Kutai itself. Also to know precisely the technique used in the construction of Rumah Kutai. With the exploration of the construction methods, especially the mortise technique, it will give a detail view to the next generation on the uniqueness of our construction method of Rumah Kutai.

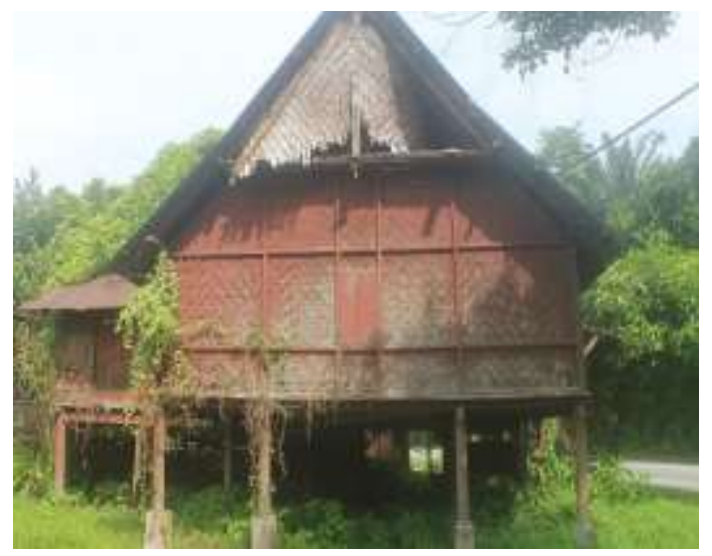

Fig.1: One of the abandoned Rumah Kutai which is located at Pasir Salak, Perak Tengah district. (Source: Author)

It is difficult for today's generation, to enjoy the privileges architecture Kutai house as this is increasingly disappearing. The main factors that led to the extinction of the Rumah Kutai this is probably due to the insensitivity of the public about the richness of the heritage, whether in terms of history or the architectural heritage of the house itself. With the advancement of technology and modernization, construction of traditional Malay house slowly been forgotten. The unique construction of Rumah Kutai has not been thoroughly identified, measured and studied in depth. Figure 1 shows one of the Rumah Kutai which had been abandoned, unoccupied.

\section{Research Objectives}

There are three objectives for the research which are to understand the sequence and 
chronological process of erecting Rumah Kutai; to identify the method of construction apply for Rumah Kutai; to document the complete construction method apply for Rumah Kutai for future reference and preservation.

\subsection{Literature Review}

\subsection{Rumah Kutai}

Rumah Kutai is an architectural heritage that can only be found in the state of Perak Darul Rizuan. Kutai means old or ancient. As stated in Vicinity Perak (2006) that these houses can be found mainly along the Perak river in three districts; Kuala Kangsar, Perak Tengah, and Pasir Salak.

Rumah Kutai has a very unique traditional long roof with a gable end. Most of the house basically has an attic at the base of the gable end, usually used for storage. The roof is made of sago (rumbia) or nipah palm. Nowadays, many Rumah Kutai owners have replaced the palm roof with zinc roofing as it is easier to maintain. Bamboo matting or kelarai is entirely used for the walls and floors ("An Article From Vicinity Perak - Rumah Kutai, The Kutai House Of Perak In Kuala Kangsar - Volume 2 Issue 9, September 2006 - Part 1," 2017). The floor of the house is raised to about two meters from the ground. The purpose of using bamboo matting is to allow natural ventilation and also to reduce glare.

The main section of the Rumah Kutai has 12 or 16 posts (Talib, 2004). The pillars or the tiang seri is made of cengal, merbau, or damar wood and come in different shapes such as round, square, or octagonal. The interesting thing about Rumah Kutai is that the pillars are not planted into the ground. It is just laid onto a base made of cut stone, bricks, or concrete. With pillars that are placed on a base, not cemented or nailed, it is very amazing that these houses can still stand tall after so many years (Nasir, 1988). The Kutai house was built so that the structure could be lifted and moved to another area. The interior is undivided and it is on the same level (Al Ahmadi, 2000). Rumah Kutai is made up of the verandah, living room, and a room. The kitchen is located at the very back of the house which is separated by an unroofed passage.

Technically, the traditional Rumah Kutai has two entrances, one for male and the other for females. The sliding doors are made low so that the guest will have to bow when people enter the house. It symbolizes as a sign of respect to the house owner which is written in ("An Article From Vicinity Perak - Rumah Kutai, The Kutai House Of Perak In Kuala Kangsar - Volume 2 Issue 9, September 2006 - Part 1," 2017). These traditional houses are fast disappearing as they are exposed to extreme weather, termites and high cost of maintenance.

\subsection{Type of Rumah Kutai}

Rumah Kutai has a basic house form and roof form. Ariffin \& Talib (2004) conducted a study on variations of Rumah Kutai between periods of 1817 to 1935 . Throughout the year, Rumah Kutai has evolved from the basic shape of house plan to the house with some additional 
spaces - based on the local needs. Basically, there are three different kinds of Rumah Kutai which are Kutai Asli, Kutai Anjung, and Kutai Anjung Beranda. From this variations, the materials and also construction methods may probably change due to the suitability of the house.

\subsection{Chronological Process - Step by Step of Erecting Rumah Kutai}

As stated by Al Ahmadi (2000) in his book about Petua Membina Rumah Melayu Dari Sudut Etnis Antropologi, the understanding and behavior of the past people practice before they erect a house in an area, they need to identify several things such as the condition and color of the soils, the day of erecting the house and also the month of the house erection which these might affect their well-being and prosperity. Noorul Huda \& Anuar (2018) stated that the relation of culture and environment plays important role in dwelling design. Different communities represent different types of culture, environment, socio-economic, religious beliefs and environmental behavior. For instance, in order to erect a house, they need to choose which month of Islam that they want to build. From their beliefs, each month has its own advantages and disadvantages. Masri (2018) quoted that heritage of all cultures and societies are rooted in the particular forms and means of tangible and intangible expression from The Nara Document of Authenticity (1994).

Besides that, Al Ahmadi (2000) also emphasizes that before erecting the first column of the house, they wrapped the column with a white cloth and recite some prayers to it. As from that practice they believe that they are asking for help from God keep them away from evil in the world and the in the hereafter. The same practice also when they want to dig a hole to place the column of the house. They recite prayers which will avoid the occupant from illness.

Faarmi (2012) has shown a video illustration on the basic construction of traditional Malay house which comprises rumah Ibu, rumah dapur, and also the beranda. From the video, it demonstrated the chronological process of erecting traditional Malay house which beginning with the footing and the placement of stumps. Then, it followed part by part until the assembling of the wall and the roof finishes.

\subsection{Construction of the Building Component in Rumah Kutai}

From the research conducted by Ariffin \& Talib (2004) on a Methodological Approach in Extensive Survey and Analysis about Perak Malay (Kutai) Architecture, they stated that the Chinese builders have a role in the building up the Malay house especially during the evolution of Rumah Kutai Anjung (the 1900s -1910s). The researchers observed that some houses are at the equal length or with even dimension. Therefore, the concluded that the material, the joinery technique and the neatness of the construction was not done by the Malay. However, the jointing system which may be done by the Chinese builders is yet to be discovered. These are the differences that will distinguish between the Malay and Chinese builders.

For this paper, the construction of the Rumah Kutai will be focusing on the six main components, which are the column components, beam to column components, floor and bendul components, roof components and its finishes, wall components, and lastly the 
staircases. Basically, these components will be emphasized on its jointing system and the tanggam type which used for the construction. Hanafi (1996) has listed the type of tanggam in his book of Pembinaan Bangunan Tradisional Melayu and Hanafi (2010) also has emphasized the basic details of the construction on Lukisan Perincian Pembinaan Bangunan Tradisional Melayu which will act as references for the details of Rumah Kutai.

\subsection{Methodology}

A literature review is conducted to provide an understanding about the architecture of Rumah Kutai and the problem facing by the traditional Malay houses especially Rumah Kutai. It involved the understanding of the type of Rumah Kutai since its existence until now, the basic process of erecting traditional Malay house, and the construction of the Rumah Kutai which emphasized on the main structural components.

In selecting the data which focused on the literature review, the data is obtained through books, journal, publications of government and statistical or history documents. Some of the articles were obtained from Google Scholar, ScienceDirect. It is also to search in detail about particular information gathered during the interview session in order to have a better understanding. Books by Hanafi (1996) Pembinaan BangunanTradisional Melayu and Hanafi (2010) Lukisan Perincian Pembinaan BangunanTradisional Melayu give a clear to decipher the detail of construction of traditional Malay houses. The ancient literature on the intangible process of erecting Rumah Kutai and the belief that the past people stick to is referred to the book by Al Ahmadi (2000) which entitled Petua Membina Rumah Melayu dari Sudut Etnis Antropologi.

However, the justification for the process of erecting Rumah Kutai and the jointing system based on its type need to be validated by an interview with the experts and the practitioner.

\subsection{Results}

\subsection{Tabulation of Rumah Kutai}

The tabulation was done by Kamal, et.al. (2013). Based on Table 1 below on the number of Rumah Kutai which is still remain existed in some part of Perak district, shows that the number is declining. It can be classified in a crucial level because it is clearly be seen that Rumah Kutai is no longer becoming the main settlement in Perak due to modernization and the numbers are expected to be lesser in coming years. It is supported by (Hassan \& Harun, 2013) in their research that the current generation prefers the modern houses over the traditional Malay houses. Number of Rumah Kutai which is still existed at Perak:

Table 1. Shows the number of Rumah Kutai in Perak.

\begin{tabular}{|l|c|}
\hline \multicolumn{1}{|c|}{ Name of Kampung } & $\begin{array}{c}\text { Number of Rumah } \\
\text { Kutai }\end{array}$ \\
\hline Kampung Kota & 1 \\
\hline Kampung Selat Pulau & 5 \\
\hline
\end{tabular}




\begin{tabular}{|l|c|}
\hline Kampung Pisang (Atas Jeti) & 2 \\
\hline Kampung Bawah Banggul & 3 \\
\hline Kampung Takir Pecah & 4 \\
\hline Kampung Pasir Salak & 4 \\
\hline Kampung Biak Hulu & 10 \\
\hline Kampung Bandar Tua & 1 \\
\hline Kampung Pasir Panjang & 1 \\
\hline Kampung Air Mati & 2 \\
\hline Kampung Ciina & 1 \\
\hline Kampung Bandar Total & 2 \\
\hline Kampung Tabian (Bayan) & 1 \\
\hline \multicolumn{2}{|c|}{ TSource } \\
\hline
\end{tabular}

(Source: Kamal, et.al., 2013)

\subsection{Illustration and Description on the type of Rumah Kutai}

Table 2 below shows the findings on the illustration and the description of the type of Rumah Kutai which indicated by Al Ahmadi (2000); Ariffin \& Talib (2004); Wong, (1995) in their research.

Table 2: Classification of Rumah Kutai

\begin{tabular}{|c|c|c|c|}
\hline $\begin{array}{l}\text { Type of Rumah } \\
\text { Kutai }\end{array}$ & Rumah Kutai Asli & Rumah Kutai Anjung & $\begin{array}{c}\text { Rumah Kutai Anjung } \\
\text { Beranda }\end{array}$ \\
\hline Illustration & $\begin{array}{c}\text { Fig.2: Kutai Asli } \\
\text { (Source: Ariffin, \& Talib) }\end{array}$ & $\begin{array}{l}\text { Fig.3: Kutai Anjung } \\
\text { (Source: Ariffin, \& Talib) }\end{array}$ & $\begin{array}{c}\text { Fig.4: Kutai Anjung } \\
\text { Beranda } \\
\text { (Source: Ariffin \& Talib) }\end{array}$ \\
\hline Description & $\begin{array}{l}\text { - From the study by } \\
\text { Ariffin \& Talib (2004) } \\
\text { and Al Ahmadi } \\
\text { (2000), they found } \\
\text { that Kutai Asli is one } \\
\text { of the earliest Rumah } \\
\text { Kutai erected by the } \\
\text { local people of Perak } \\
\text { (Fig. } 2 \text { ). } \\
\text { It is believed that } \\
\text { Kutai Asli house } \\
\text { existed circa } 1817 \text { to } \\
\text { 1900s. } \\
\text { Since Kutai Asli is the } \\
\text { first to be established, } \\
\text { hence it has a very }\end{array}$ & $\begin{array}{l}\text { - During the year } 1900 \\
\text { to } 1910 \text { s, the Kutai } \\
\text { Asli had a slightly } \\
\text { changed on its form. } \\
\text { - Also the addition of } \\
\text { interior spaces. } \\
\text { It is called Kutai } \\
\text { Anjung house. } \\
\text { - Ariffin \& Talib } \\
\text { (2004); Talib (2004) } \\
\text { stated that Kutai } \\
\text { Anjung consists of } \\
\text { rumah ibu and } \\
\text { addition of anjung } \\
\text { area (Fig.3). }\end{array}$ & $\begin{array}{l}\text { Kutai Anjung } \\
\text { Beranda is which the } \\
\text { Rumah Kutai } \\
\text { evolved in terms of } \\
\text { addition of extra } \\
\text { spaces that affect the } \\
\text { space utilization of } \\
\text { the house, also the } \\
\text { shape of the house } \\
\text { itself as shown in Fig. } \\
\text { 4. } \\
\text { It is believed that the } \\
\text { construction of Kutai } \\
\text { Anjung Beranda is } \\
\text { within the year } 1920\end{array}$ \\
\hline
\end{tabular}




\begin{tabular}{|c|c|c|c|}
\hline & $\begin{array}{l}\text { basic interior } \\
\text { arrangement, which } \\
\text { consisted of Rumah } \\
\text { lbu (main house) and } \\
\text { rumah tangga } \\
\text { (staircase "house"). } \\
\text { Basically, there two } \\
\text { types of Kutai Asli } \\
\text { which are Kutai Asli } \\
\text { with } 12 \text { columns and } \\
\text { Kutai Asli with } 16 \\
\text { columns. } \\
\text { Kutai Asli used } \\
\text { Bumbung panjang or } \\
\text { long roof type of roof } \\
\text { which has simple } \\
\text { pitch roof ranging } \\
\text { from 50' to } 60 \text { ' with } \\
\text { cantilevered gable- } \\
\text { end walls on both } \\
\text { sides of the Rumah } \\
\text { lbu. }\end{array}$ & $\begin{array}{l}\text { - Anjung is an } \\
\text { additional frontage } \\
\text { space 'protruding' } \\
\text { from the original } \\
\text { rumah ibu (Kutai Asli } \\
\text { house), placed } \\
\text { perpendicular and } \\
\text { extended from the } \\
\text { center front of rumah } \\
\text { ibu. } \\
\text { The addition makes } \\
\text { the shape of the } \\
\text { house to 'T' shapes. }\end{array}$ & 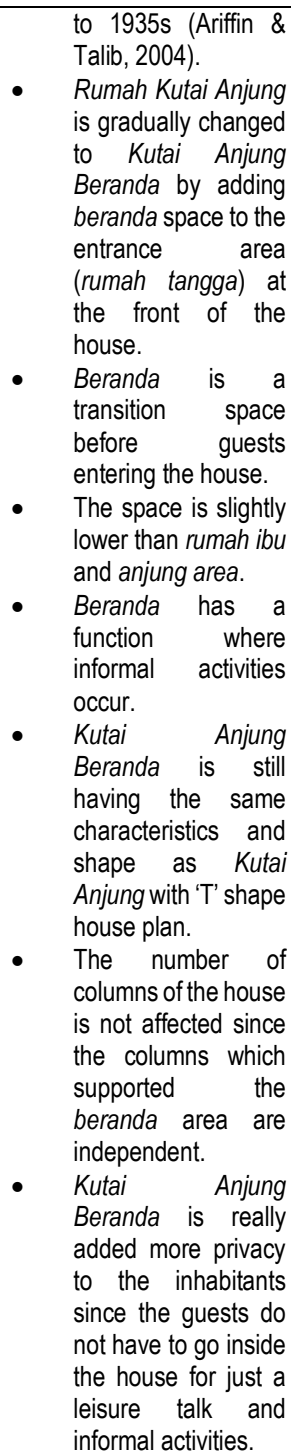 \\
\hline
\end{tabular}

(Source: Al Ahmadi, 2000; Ariffin \& Talib, 2004; Wong, 1995)

\subsection{Chronological Process of Erecting Rumah Kutai}

Table 3 below are the few examples for Islamic months and its sequences if people build a house in that particular month. 
Table 3. Shows the example of Islamic months and its sequences if people erect a house in that particular month.

\begin{tabular}{|c|l|}
\hline Islamic Month & \multicolumn{1}{c|}{ Advantages/ Disadvantages } \\
\hline Muharram & It gives chaos and evil to the owner of the house. \\
\hline Safar & It gives wealthy to the owner. \\
\hline Rabiulawal & The owner of the house may die. \\
\hline Rabiulakhir & The owner of the house lives in a state of prosperity \\
\hline
\end{tabular}
(Source: Al Ahmadi, 2000)

The construction process of erecting Rumah Kutai is started with pad footing. This pad footing is the concrete base for the placement of columns for the house. Once the pad footing is in place, then concrete stumps are placed on top of the footing. The columns are erected on top of the concrete stumps. The number of columns of Rumah Kutai can be 12 or 16 columns depends on the status and wealth of the owner. The columns erection are first started to build in the rumah ibu area. Then followed by kitchen area and lastly anjung (Fig. $5)$.

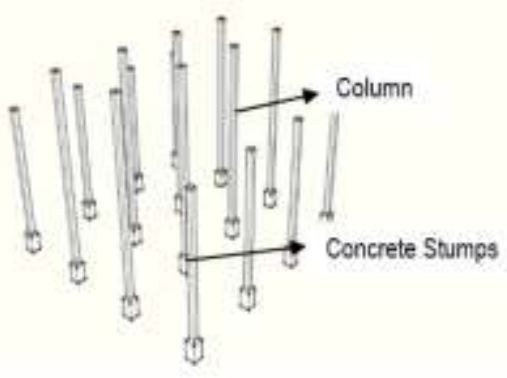

Fig. 5: The erection of columns.

(Source: Author)

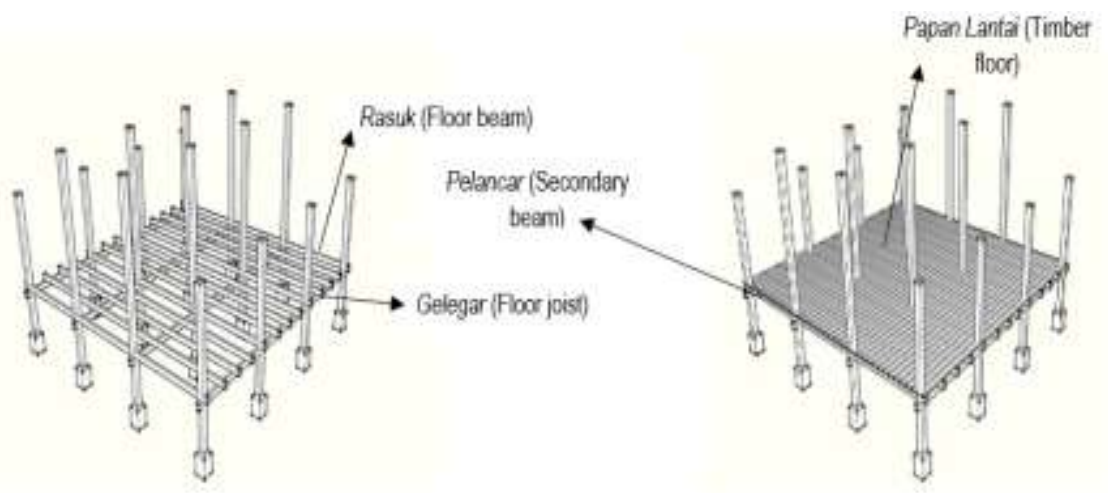

Fig. 6: The installation of gelegar, pelancar, rasuk and also the papan lantai.

(Source: Author) 
Once the columns have been erected, pelancar (secondary beam) is placed at the columns. It functions is to align the position of the columns. When the columns are aligned, rasuk (floor beam) is inserted at the columns. This is to support the loads, gelegar (floor joist) and the floor itself. Once the columns and floor beams are nicely joint and stable, then the papan lantai (timber boards) are placed at the top of the floor beams. The timber board is the platform to carry the live and dead loads. (Fig. 6)

Then, the house is further constructed at the roof part. The roof part is first started with alang panjang (long tie-beam) which is placed at the top of every column. Then followed by alang pendek (short tie-beam) which is placed with opposite direction of alang panjang. Once the long tie-beam and short tie-beam is nicely placed and secured at its position, the tunjuk langit (king post) is placed on top and in the middle of every short tie-beam (Fig 7).
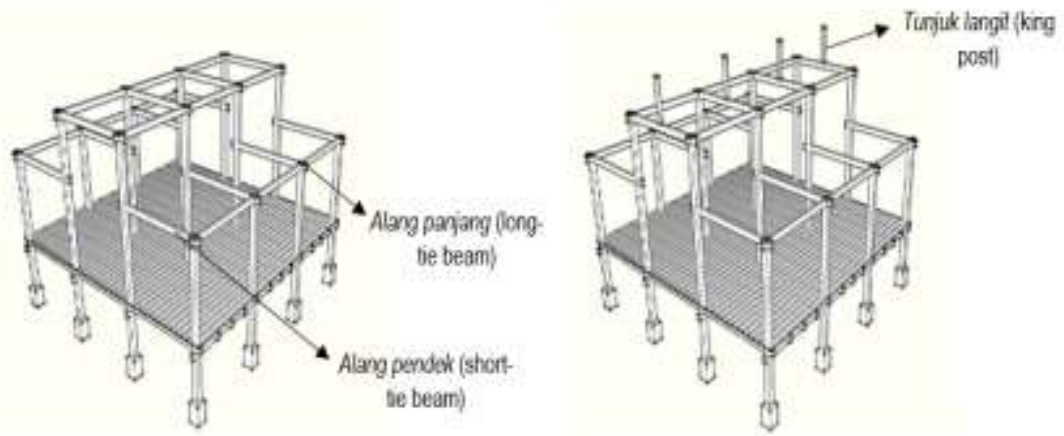

Fig. 7: The installation of alang panjang, alang pendek and tunjuk langit.

(Source: Author)

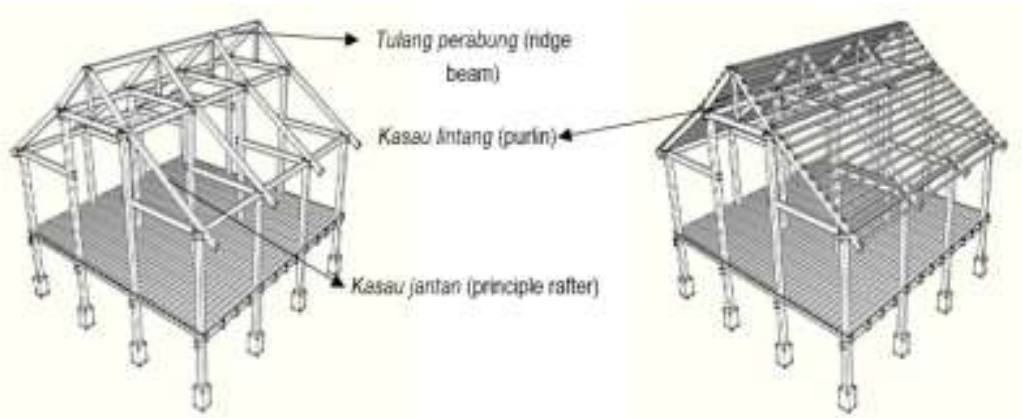

Fig. 8: The installation of tulang perabung, kasau lintang, and kasau jantan.

(Source: Author)

Next, kasau jantan (principle rafter) are arranged with a specific angle of the roof which ranges within angle $50^{\circ}$ to $60^{\circ}$ (Ariffin \& Talib, 2004) and followed by tulang perabung (ridge 
beam) at the very top of the roof. Before the roof is covered with nipah leaves, kasau lintang (purlin) is placed and arranged accordingly on top of the principle rafter. After that, roof cover like nipah leaves or zinc is placed on top of it to cover the interior of the whole house (Fig. 8).

Some of the traditional houses have kasau lintang/kasau panjang, kasau betina, and jeria/gulung-gulung. This is like another layer of the roof part which is bear the load of the roof cover and also to strengthen the roof structure from the outside pressure such as strong wind and heavy rain. When the structure is completely assembled and secured, then the other parts of the house like walls, doors, windows, and staircase are placed to complete the whole house. The house is then ready to be occupied.

\subsection{Components in Rumah Kutai and its general jointing system}

Table 4 below elaborate on the particular components of Rumah Kutai which are the columns, beam to column, floor and bendul, roof, wall, and staircases.

Table 4: Jointing system for particular components in Rumah Kutai

\begin{tabular}{|c|c|c|}
\hline Component & Illustration & $\begin{array}{l}\text { Description } \\
\end{array}$ \\
\hline Columns & Fig. 9: The function of the base for & $\begin{array}{l}\text { - The column is the most important } \\
\text { component to build a house. } \\
\text { The number of columns depends on } \\
\text { the status of the owner. } \\
\text { Before start erecting columns for } \\
\text { most of the traditional Malay house, it } \\
\text { must need a concrete base (pelapik) } \\
\text { in order to support the column itself } \\
\text { from sinking into the soil shown in Fig. } \\
\text { 9. } \\
\text { The base of the column comes in } \\
\text { many types shown in Fig. } 10 \text { (Hanafi, } \\
\text { 1996). } \\
\text { The joinery between the column and } \\
\text { the base is using tanggam putting } \\
\text { dan tebuk system (Hanafi, 1996) } \\
\text { shown in Fig. } 11 . \\
\text { Puting is a tip of the bottom part of the } \\
\text { column which will insert in the hole at } \\
\text { the base provided. } \\
\text { The reason why the column is placed } \\
\text { on top of the base by using puting is } \\
\text { to avoid the column from shifting } \\
\text { away from the base. The other reason } \\
\text { is that the past people believe that, } \\
\text { when the owner wanted to move to a } \\
\text { new area, they need to move the } \\
\text { house as well. } \\
\text { Therefore, they can lift the house and } \\
\text { move it to another area (Kamal et al., } \\
2013 \text { ). }\end{array}$ \\
\hline
\end{tabular}




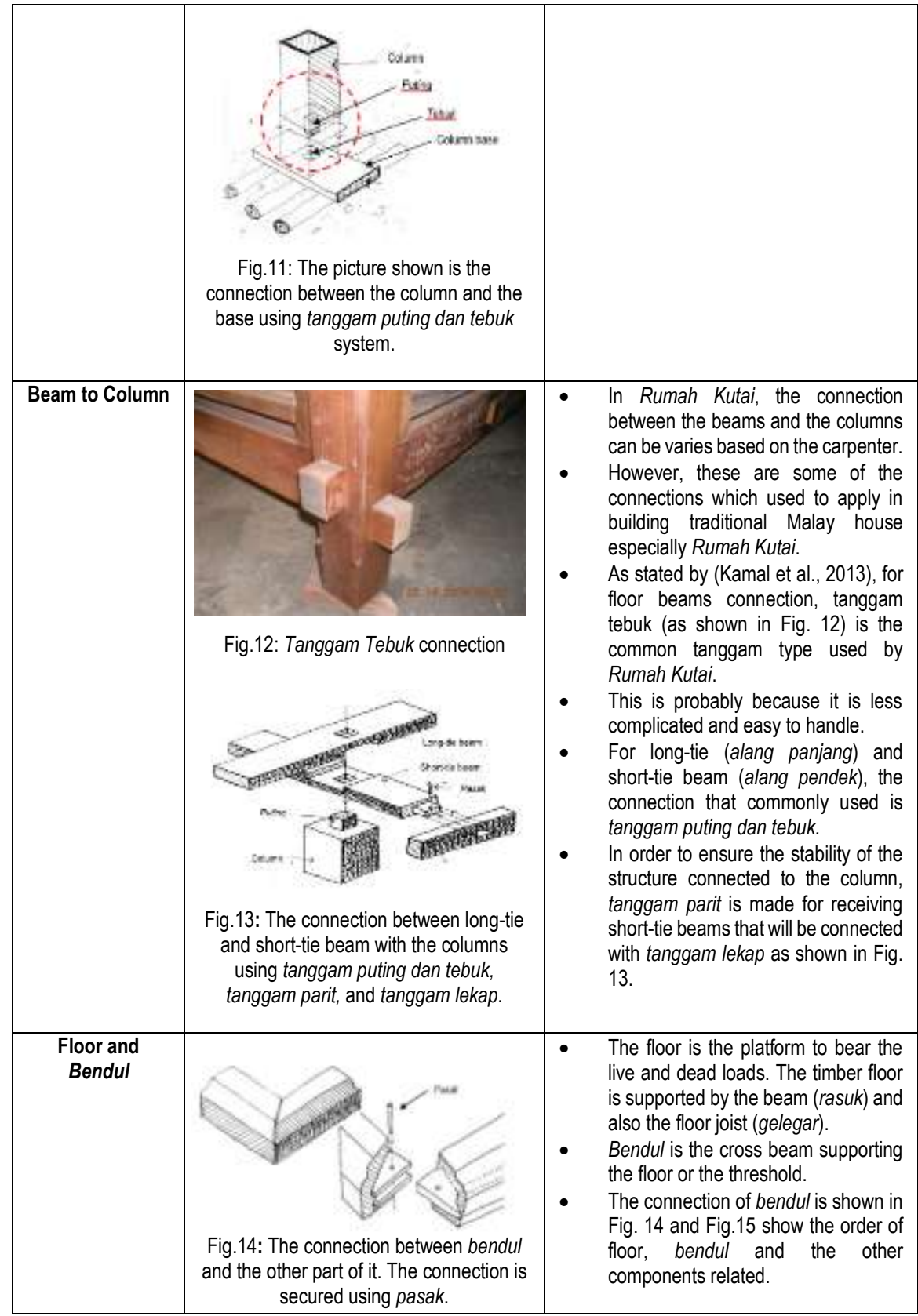




\begin{tabular}{|c|c|c|}
\hline & Fig.15: Floor and Bendul components & \\
\hline Roof & Fig.16: Roof components. & $\begin{array}{l}\text { - The roof components are as shown in } \\
\text { the Fig. } 16 \text { (Hanafi, 1996) }\end{array}$ \\
\hline Wall & Fig.17: Slot in timber wall & $\begin{array}{l}\text { - Wall is the component which } \\
\text { constructed after the structure of the } \\
\text { Rumah Kutai completely erected and } \\
\text { secured. } \\
\text { Some of Rumah Kutai are using } \\
\text { normal timber wall and some of it is } \\
\text { using bamboo matting wall (kelarai } \\
\text { wall). } \\
\text { However, most of Rumah Kutai are } \\
\text { using panel wall in which the panels } \\
\text { are prepared on site and assembled } \\
\text { at the structure. } \\
\text { It is called a slot in wall (Fig. 17). } \\
\text { The difference of wall used is } \\
\text { representing the position of the owner } \\
\text { and also to show the wealth of the } \\
\text { owner. }\end{array}$ \\
\hline Staircase & & $\begin{array}{l}\text { - The staircase is also the components } \\
\text { of Rumah Kutai which assembled } \\
\text { after the wall. } \\
\text { For the basic of Rumah Kutai, there } \\
\text { will be two main staircases which }\end{array}$ \\
\hline
\end{tabular}




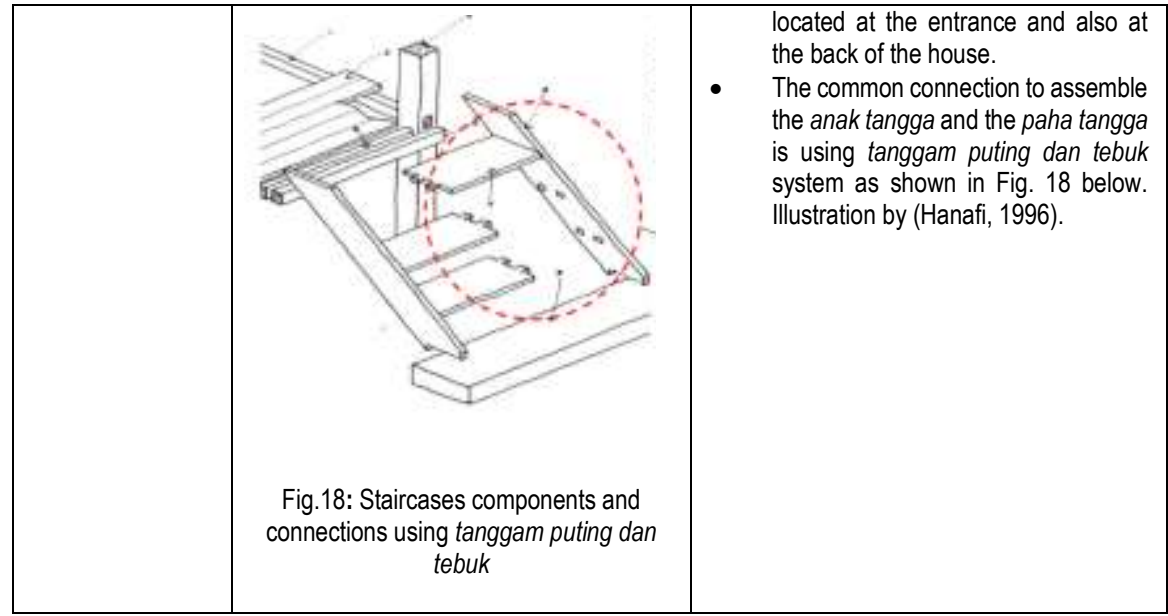

(Source: Hanafi, 1996)

\subsection{Discussion}

This study is first to demonstrate the construction techniques apply for Rumah Kutai. The writing of the literature review has basically done and still searching some of the articles which related to the research to validate the finding and strengthen the obtained information. However, the research still needs to be completed with the interview and case study.

The finding on the architecture of Rumah Kutai has given some detail information which distinguished Rumah Kutai with other traditional Malay houses. The literature review on the architecture of Rumah Kutai is to give a basic understanding on Rumah Kutai as a whole, the origin, and the history of Rumah Kutai before the research further discuss on the construction part. Few articles are as references and also used to support the information gathered.

The study done by (Al Ahmadi, 2000; Ariffin \& Talib, 2004; Talib, 2004; Wong, 1995) on the type of Rumah Kutai has confirmed their research on the three different type of Rumah Kutai which are Rumah Kutai Asli, Rumah Kutai Anjung, and Rumah Kutai anjung Beranda. The type of Rumah Kutai is clearly described. However, the data collection is needed to be done on the interview and case study to investigate their process of erecting the house, and also to study the jointing system which has precise on the literature review. The general step by step process of erecting traditional Malay houses gives the understanding of how the house is erected.The step by step of this particular Rumah Kutai needs to be measured by interviewing the expert in order to know which of the spaces come first in the process of building it. Indeed, the different type or Rumah Kutai will have a different process since there is an additional of space through its evolution.

The construction details of the jointing system is a general overview on how the particular components are connected with another component of the house. A book on Pembinaan 
Bangunan Tradisional Melayu written by (Hanafi, 1996) gives a vast information on determining the type of tanggam used by the components. However, the groundwork by going to the site and determine the tanggam type is needed to be done in order to know the specific jointing system and also the material used by the house.

Based on all the gathered information, the research is still in an early process of the literature review. Semi-structured interview and case study are required to be done to validate the findings and to achieve the objectives of the research.

\subsection{Conclusion}

The findings of the study had identified the general overview on the construction technique of Malay traditional house, Rumah Kutai and the types of tanggam jointing system. However, the info which related to Rumah Kutai is yet to be determined and finalized by doing the data collection and analysis on the case study and interview. The study aimed to document the construction technique of Rumah Kutai, Perak and contribute to Malaysia that this documentation will be the future reference for the next generation to decipher traditional Rumah Kutai. Theoretically, this study supports the past literature in terms of the type of Rumah Kutai and the construction process of the house. Practically, it also serves a useful reference on the jointing system with a detail specification, which can be practiced and also applied in coming decades in order to ensure it will not disappear from the knowledge of our people.

The Malay traditional construction technique is rarely practiced by the current generation since the technology has taken over the world. The higher council such as Pertubuhan Arkitek Malaysia (PAM) or the heritage corporation need to take this declination of traditional Malay houses as a crucial case. They need to secure the information of the traditional houses by doing more research and creating replicas or incorporate the traditional design into the modern houses so that it could be more appreciated and recognized by the generation. It is an opportunity to discover and document this construction technique as it is somehow influenced by the cultural practice, and can indirectly explore the local community of the area. By doing this, it will provide more chances of doing further research as well as a way of documenting our culture and tradition to be conserved for the next generation.

\section{References}

Al Ahmadi, A. R. (2000). Petua Membina Rumah Melayu Dari Sudut Etnis Antropologi.

An Article From Vicinity Perak - Rumah Kutai, The Kutai House Of Perak In Kuala Kangsar - Volume 2 Issue 9 , September 2006 - Part 1. (2017), 11-12.

Ariffin, M. ., \& Talib, A. (2004). Perak Malay (Kutai) Architecture: a Methodological Approach in Extensive Survey and Analysis, 1-12.

Faarmi. (2012). Basic Construction of Malay Traditional House. 
Hanafi, Z. (1996). Pembinaan Bangunan Tradisional Melayu (1st ed.). Amber Solara Publication.

Hanafi, Z. (2010). Lukisan Perincian Pembinaan Bangunan Tradisional Melayu.

Hassan, Z., \& Harun, S. N. (2013). Preservation of Malay Singgora Roof. Procedia Environmental Sciences, 17, 729-738. https://doi.org/10.1016/j.proenv.2013.02.090

Kamal, K. S., A.Wahab, L., \& Majid, M. F. (2013). IRDC Research Documentation Project of Kutai House (Rumah Kutai), Bota, Perak, Malaysia, 166(December 2006), 157-166. Retrieved from http://buildingconservation.blogspot.my/2007/03/documentation-project-of-kutai-house_21.html

Masri, M. (2018). The Misconceptions of Negeri Sembilan Traditional Architecture. Procedia - Social and Behavioral Sciences, 68(8), 363-382. https://doi.org/10.1016/j.sbspro.2012.12.234

Noorul Huda, M. R., \& Anuar, T. (2018). The Privacy Aspects in the Malay Dwelling. Asian Journal of ENvironmentBehaviour Studies, ajE-Bs, 5(20), 103-114. https://doi.org/10.21834/ajbes.v3i11.111

Sabil, A. Bin, \& Utaberta, N. (2011). Documentation and analysis of sustainable design and application of Tanggam System in Malay traditional house. Advanced Materials Research, 291-294, 984-987. https://doi.org/10.4028/www.scientific.net/AMR.291-294.984

Talib, A. (2004). Establishing the Architectural Definition / Inventory of the Traditional Perak Malay Kutai Houses ( of the 1820 ' S - 1900 ' S ) and Its Potentials for the Purpose of Restoration, Conservation and Tourism, 1-22.

Wong, W. (1995). Timber Structures in Malaysian Architecture and Buildings, (March), 305. 